\title{
Penerapan Teori Belajar Bermakna untuk Meningkatkan Literasi Matematis Siswa Kelas X
}

\author{
Nur Wiji Sholikin ${ }^{1}$, Imam Sujarwo ${ }^{2}$, Abdussakir ${ }^{3}$ \\ 1, 2, 3 Program Magister Pendidikan Matematika, Fakultas Ilmu Tarbiyah dan Keguruan, Universitas Islam Negeri Maulana \\ Malik Ibrahim Malang, Jl. Tarbiyah, Dinoyo, Kec. Lowokwaru, Kota Malang, Jawa Timur, Indonesia \\ nur.wiji.s.002@gmail.com
}

\begin{abstract}
The problem in this research is the low mathematical literacy ability of class X students which is found in the material of a three-variable system of linear equations. This is due to the weak ability of students to analyze, analyze and represent mathematical problem solving related to real-world situations. The purpose of this study was to improve the mathematical literacy of class $X$ students after receiving learning with meaningful learning theory. The research method used is the experimental research method with pretest and posttest given to the experimental class and control class. The research subjects were students of Madrasah Aliyah class X which consisted of 14 students in the experimental class and 13 students in the control class. The instrument used in this study is a matter of mathematical literacy ability test. The results showed that the increase in students' mathematical literacy skills in the experimental class was in the high category. Based on the results of this study, it can be seen that the application of meaningful learning theory can improve the mathematical literacy ability of class X students.
\end{abstract}

Keywords: Meaningful Learning Theory, Mathematical Literacy, Student Class X

\begin{abstract}
Abstrak
Masalah dalam penelitian ini adalah kemampuan literasi matematis siswa kelas X rendah yang ditemukan pada materi sistem persamaan linear tiga variabel. Hal tersebut disebabkan kemampuan siswa lemah dalam menganalisis, menafsirkan dan merepresentasikan pemecahan masalah matematika yang berkaitan dengan situasi dunia nyata. Tujuan penelitian ini adalah untuk meningkatkan literasi matematis siswa kelas X setelah mendapatkan pembelajaran dengan teori belajar bermakna. Metode penelitian yang digunakan yaitu metode penelitian eksperimen dengan pretest dan posttest yang diberikan pada kelas eksperimen dan kelas kontrol. Subjek penelitian yaitu siswa Madrasah Aliyah kelas X yang terdiri dari 14 siswa pada kelas eksperimen dan 13 siswa pada kelas kontrol. Instrumen yang digunakan dalam penelitian ini adalah soal tes kemampuan literasi matematis. Hasil penelitian menunjukkan, peningkatan kemampuan literasi matematis siswa di kelas eksperimen berada pada kategori tinggi. Berdasarkan hasil penelitian tersebut dapat diketahui bahwa penerapan teori belajar bermakna dapat meningkatkan kemampuan literasi matematis siswa kelas X.
\end{abstract}

Kata Kunci: Teori Belajar Bermakna, Literasi Matematis, Siswa Kelas X

Copyright (c) 2022 Nur Wiji Sholikin, Imam Sujarwo, Abdussakir

$\triangle$ Corresponding author: Nur Wiji Sholikin

Email Address: nur.wiji.s.002@gmail.com (Jl. Tarbiyah, Dinoyo, Kec. Lowokwaru, Kota Malang, Jawa Timur) Received 04 December 2021, Accepted 18 January 2022, Published 19 January 2022

\section{PENDAHULUAN}

Literasi matematis merupakan kecakapan seseorang dalam menggunakan konsep matematika untuk menyelesaikan masalah dalam konteks kehidupan nyata (Han, Weilin, 2017; Sumirattana et al., 2017). Literasi matematis juga diartikan sebagai kemampuan menggunakan kapasitas pengetahuan dan pemahaman matematika untuk menyelesaikan permasalahan kehidupan sehari-hari (Burkhardt, 2003). Literasi matematis mencakup 1) sifat matematika, 2) konsep matematika, 3) kemampuan matematika, dan 4) aplikasi matematika yang relevan dengan kehidupan nyata (Nagasaki, 2015). Berdasarkan beberapa definisi tersebut literasi matematis dapat diartikan sebagai kemampuan 
Penerapan Teori Belajar Bermakna untuk Meningkatkan Literasi Matematis Siswa Kelas X, Nur Wiji Sholikin, Imam Sujarwo, Abdussakir

merumuskan, menggunakan, dan menafsirkan konsep matematika dengan mengaitkan pengalaman kehidupan nyata.

Kemampuan literasi matematis merupakan tujuan pokok yang harus dicapai dalam pembelajaran matematika. Karena literasi matematis merupakan kemampuan mengimplementasikan konsep-konsep matematika dalam kehidupan sehari-hari. Sehingga matematika tidak hanya dipahami dan digunakan sebagai alat untuk menghitung saja tetapi juga dapat digunakan sebagai alat untuk mempermudah seseorang dalam menyelesaikan berbagai urusan. Selain itu literasi matematis juga memiliki peran penting dalam mengembangkan keterampilan berpikir kritis, kreatif, dan kemampuan pemecahan masalah (Prihatmojo et al., 2019; Nagasaki, 2015).

Fakta di lapangan, kemampuan literasi matematis siswa berada pada kategori rendah. Hal ini, ditunjukkan dari hasil penelitian yang dilakukan oleh PISA yang menyatakan bahwa literasi matematis siswa berada pada skor 379 dan jauh dari nilai standar yang ditentukan (OECD 2019). Hal ini disebabkan oleh beberapa faktor diantaranya siswa kesulitan membuat pemodelan matematika dari konteks kehidupan sehari-hari (Hayati \& Kamid, 2019). Matematika hanya dipahami siswa sebagai hasil hitung di bangku sekolah tanpa dipahami kegunaannya dalam kehidupan nyata, siswa menggunakan prosedur hafalan ketika menyelesaikan masalah matematika tanpa memahami proses dan setruktur yang mendasarinya, dan guru kesulitan mengaitkan topik materi matematika dengan nilai-nilai kehidupan siswa (Bolstad, 2019). Kemampuan siswa lemah dalam menganalisis, menafsirkan dan merepresentasikan pemecahan masalah matematika yang berkaitan dengan situasi dunia nyata (Umbara \& Suryadi, 2019).

Temuan lain melaporkan penyebab rendahnya literasi matematis pada materi sistem persamaan linear tiga variabel antara lain, kemampuan siswa lemah dalam menganalisis, menafsirkan dan merepresentasikan pemecahan masalah matematika yang berkaitan dengan situasi dunia nyata (Zulaikah \& Sujadi, 2017; Umbara \& Suryadi, 2019). Guru kesulitan mengaitkan topik materi matematika dengan nilai-nilai kehidupan siswa (Bolstad, 2019). Berdasarkan kesulitan tersebut menjadikan siswa terkendala dalam merumuskan, menafsirkan, dan menggunakan konsep matematika yang berkaitan dengan sistem persamaan linear tiga variabel pada konteks kehidupan nyata. Sehingga akan berdampak buruk pada perkembangan kemampuan literasi matematis siswa.

Memperhatikan kondisi tersebut meningkatkan kemampuan literasi matematis siswa dalam pembelajaran matematika menjadi sangat penting. Banyak cara yang dapat dilakukan untuk meningkatkan literasi matematis siswa, mulai dari pemenuhan sumber belajar dan lingkungan belajar yang mendukung untuk peningkatan kemampuan literasi matematis. Selain itu juga dapat dilakukan melalui kegiatan pembelajaran di kelas dengan menerapkan teori pembelajaran yang sesuai dengan kebutuhan dan kondisi siswa. Salah satunya dengan menerapkan teori belajar bermakna David Ausubel yang lebih cenderung mengaitkan kegiatan pembelajaran dengan kehidupan nyata siswa. Hal ini, sejalan dengan kurikulum 2013 yang lebih menekankan pada penerapan pembelajaran kontekstual. 
Teori belajar bermakna David Ausubel memiliki kesamaan dengan teori konstrukstivisme yaitu sama-sama menekankan tentang pentingnya siswa mengasosiasikan pengalaman, fenomena, dan fakta-fakta baru ke dalam sistem pengetahuan yang dimiliki untuk menyelesaikan masalah sehari-hari (Gazali, 2016). Teori belajar bermakna mengungkapkan bahwa belajar yang bermakna merupakan hasil rekonstruksi pengalaman berdasarkan informasi-informasi baru yang relevan dengan struktur kognitif (Majdi, 2019). Teori belajar bermakna, lebih menekankan pada kemampuan kognitif siswa dalam mengkonstruksikan pengalaman dan fenomena baru tentang apa yang dipelajari sebagai struktur pengetahuan dalam penyelesaian masalah secara open ended (Ariyanto, 2012).

Beberapa penelitian terdahulu yang menerapkan teori belajar bermakna David Ausubel dalam pembelajaran matematika, seperti penelitian yang dilakukan oleh (Ariyanto, 2012) yang melaporkan bahwa melalui penerapan teori belajar bermakna kegiatan pembelajaran yang dilakukan di kelas menjadi lebih efektif dan efisien. Hal ini dikarenakan dengan belajar bermakna daya ingat siswa semakin kuat, sehingga siswa dapat mengkonstruksikan pengetahuan dan pengalaman belajar yang pernah dialami untuk menyelesaikan masalah sehari-hari yang berkaitan dengan matematika. Hasil penelitian (Saputra, 2016) juga melaporkan bahwa melalui penerapan teori belajar bermakna David Ausubel minat belajar matematika siswa meningkat. Hal ini dikarenakan pada teori belajar bermakna David Ausubel lebih cenderung mengaitkan materi matematika dengan kehidupan nyata siswa, sehingga siswa lebih cepat memahami materi matematika yang diberikan berdasarkan pengetahuan dan pengalaman yang dimiliki.

Beberapa penelitian terdahulu yang telah melakukan penelitian peningkatan literasi matematis siswa seperti (Sari \& Khiyarunnisa, 2017) yang melaporkan bahwa peningkatan kemampuan literasi matematis siswa dapat ditingkatkan melalui penerapan pembelajaran problem based learning. Kegiatan pembelajaran yang dilakukan dengan cara memberikan permasalahan kontesktual kepada siswa untuk dikerjakan melalui diskusi kelompok. Hasil penelitian (Ahmad \& Nasution, 2019) melaporkan bahwa peningkatan kemampuan literasi matematis siswa dapat ditingkatkan melalui pendekatan kontekstual. Kegiatan pembelajaran yang dilakukan dititikberatkan pada keterlibatan aktif siswa dalam menemukan konsep matematika melalui pemanfaatan keterkaitan materi dengan situasi dunia nyata.

Hasil penelitian terdahulu sejalan dengan teori belajar bermakna David Ausubel yang lebih menekankan pembelajaran matematika berorientasi pada kehidupan nyata siswa. Hal ini sesuai dengan pembelajaran yang digunakan untuk meningkatkan kemampuan literasi matematis menurut PISA tahun 2018 yakni pembelajaran yang dikaitkan dengan aktivitas kehidupan sehari-hari siswa. Sehingga, peneliti berasumsi bahwa penerapan teori belajar bermakna David Ausubel dapat meningkatkan kemampuan literasi matematis siswa.

Berdasarkan uraian diatas belum ada penerapan teori belajar bermakna untuk meningkatkan kemampuan literasi matematis siswa kelas X. Karena belum ada jadi perlu diterapkan dalam pembelajaran di kelas. Adapun cakupan materi yang masih ditemukan masalah sehingga perlu 
Penerapan Teori Belajar Bermakna untuk Meningkatkan Literasi Matematis Siswa Kelas X, Nur Wiji Sholikin, Imam Sujarwo, Abdussakir

dikembangkan pada materi sistem persamaan linear tiga variabel untuk jenjang Madrasah Aliyah kelas X.

\section{METODE}

Penelitian ini menggunakan metode penelitian eksperimen. Peneliti, melakukan penelitian ini di Madrasah Aliyah Daruttauhid Malang. Subjek dalam penelitian ini terdiri dari 27 siswa kelas X yakni 14 siswa dari kelas eksperimen dan 13 siswa dari kelas kontrol. Pada kelas eksperimen diberikan perlakuan berupa penerpan teori belajar bermakna David Ausubel. Sedangkan pada kelas kontrol tidak diberikan perlakuan dan menggunakan teori belajar yang lain.

Instrumen penelitian yang digunakan untuk mengetahui pencapaian kemampuan literasi matematis siswa berupa soal tes yang berbentuk uraian dan terdiri atas 2 butir soal permasalahan sehari-hari yang berkaitan dengan sistem persamaan linear tiga variabel. Soal tes disusun berdasarkan kompetensi dasar dan indikator literasi matematis yang diperoleh dari PISA. Sebelum soal tes digunakan kepada siswa, soal tes divalidasi oleh 3 ahli yang memiliki kualifikasi yakni dosen pendidikan matematika, pendidikan terakhir S3 (strata 3) matematika/pendidikan matematika, dan memiliki pengalaman mengajar minimal 5 tahun. Sedangkan diagram alur perancangan soal tes kemampuan literasi matematis seperti yang terdapat pada Gambar 3.1.

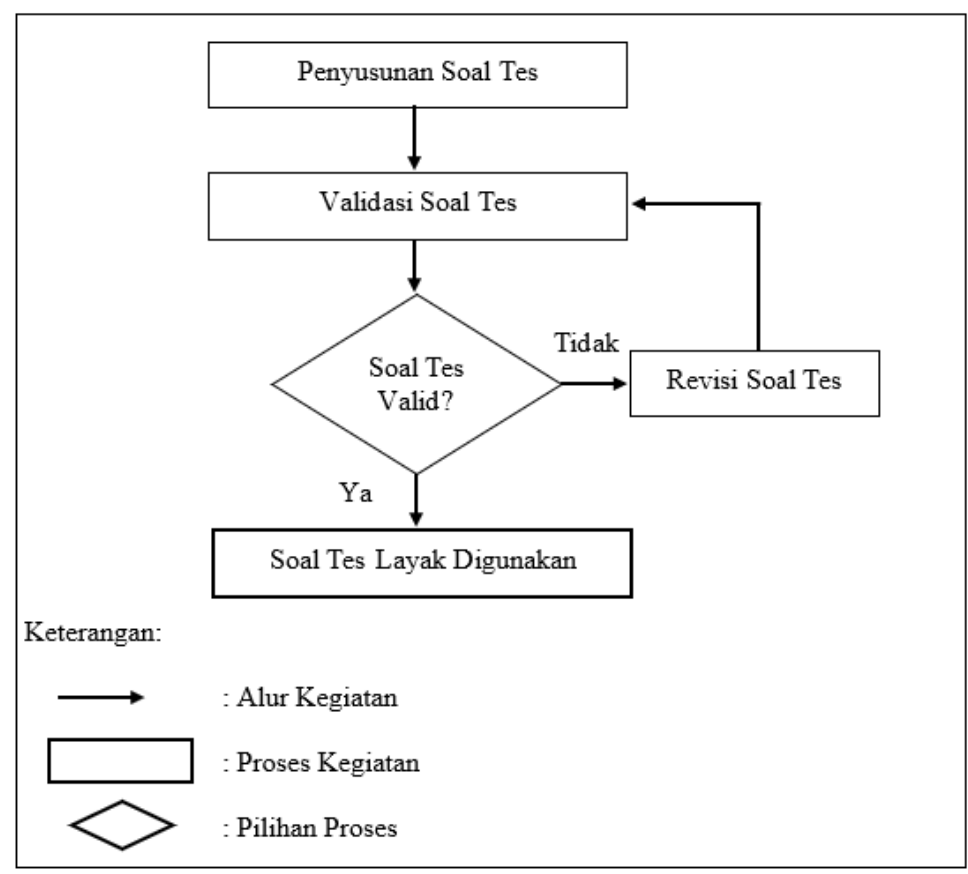

Gambar 1. Diagram Alur Perancangan Soal Tes Kemampuan Literasi Matematis

Sebelum dilakukan kegiatan pembelajaran, peneliti memberikan pretest terlebih dahulu kepada siswa dari kelas eksperimen dan kelas kontrol. Tujuan dilakukan pretest tersebut untuk mendiagnosis kemampuan awal literasi matematis siswa dari kedua kelas sebelum diberikan perlakuan. Untuk mengetahui apakah ada kesamaan atau ada perbedaan yang signifikan kemampuan awal literasi 
matematis kedua kelas, dari hasil pretest dilakukan uji coba statistik non parametrik yaitu uji statistik Mann Whitney.

Dasar pengambilan keputusan uji Mann Whitney berdasarkan hasil pretest dan posttest kemampuan lieterasi matematis siswa sebagai berikut.

1. Jika nilai Asymp. Sig. $<0,05$, maka hipotesis diterima

2. Jika nilai Asymp. Sig. $>0,05$, maka hipotesis ditolak

Hipotesis: ada perbedaan hasil peningkatan kemampuan literasi matematis siswa anatara kelas eksperimen dan kelas kontrol.

Setelah dilakukan pretest dan diketahui ada kesamaan kemampuan awal literasi matematis siswa kelas X. Selanjutnya, peneliti lakukan perlakuan yaitu penerapan teori belajar bermakna pada kelas eksperimen. Peneliti lakukan posttest kepada siswa dari kelas eksperimen dan kelas kontrol. Untuk mengetahui apakah ada kesamaan atau ada perbedaan yang signifikan kemampuan awal literasi matematis kedua kelas, dari hasil pretest dilakukan uji coba statistik non parametrik yaitu uji statistik Mann Whitney.

Setelah dilakukan uji statistik Mann Whitney dan ditunjukkan ada perbedaan kemampuan literasi matematis siswa antara kelas eksperimen dan kelas kontrol. Selanjutnya, untuk mengetahui naik tinggi atau rendahnya perbedaan itu, peneliti lakukan uji N-gain. Adapun rumus perhitungan skor Ngain yang digunakan adalah sebagai berikut.

$$
\text { Gain Ternormalisasi }\langle g\rangle=\frac{S_{\text {post }}-S_{\text {pre }}}{S_{m \_ \text {ideal }}-S_{\text {pre }}}
$$

\section{Keterangan:}

$\langle g\rangle \quad=$ skor rata-rata gain yang dinormalisasi

$S_{\text {post }} \quad=$ skor rata-rata tes akhir siswa

$S_{\text {pre }} \quad=$ skor rata-rata tes awal siswa

$S_{m \_ \text {ideal }}=$ skor maksimum ideal

Sedangkan perolehan nilai rata-rata $\mathrm{N}$-Gain yang didapat diinterpretasikan berdasarkan kriteria gain pada Tabel 2.

Tabel 2. Interpretasi Skor Rata-rata N-Gain

\begin{tabular}{|c|c|}
\hline$\langle\boldsymbol{g}\rangle$ & Kriteria \\
\hline$\langle g\rangle \geq 0,7$ & Tinggi \\
\hline $0,3 \leq\langle g\rangle<0,7$ & Sedang \\
\hline$\langle g\rangle<0,3$ & Rendah \\
\hline
\end{tabular}

(Hake, 1999)

\section{HASIL DAN DISKUSI}

Penelitian ini dilakukan di Madrasah Aliyah Daruttauhid Malang. Subjek yang diambil sebanyak 27 siswa kelas X yang terdiri dari 14 siswa dari kelas eksperimen dan 13 siswa dari kelas kontrol. 
Penerapan Teori Belajar Bermakna untuk Meningkatkan Literasi Matematis Siswa Kelas X, Nur Wiji Sholikin, Imam Sujarwo, Abdussakir

Materi yang digunakan dalam penelitian ini yakni materi sistem persamaan linear tiga variabel. Peneliti menggunakan materi tersebut karena lebih mudah jika dikaitkan dengan kehidupan nyata siswa, sehingga sesuai dengan teori belajar bermakna yang lebih cenderung menekankan pada pembelajaran yang berorientasi pada kehidupan sehari-hari siswa. Penelitian ini dilakukan untuk mengetahui apakah penerapan teori belajar bermakna lebih baik dalam meningkatkan kemampuan literasi matematis siswa kelas $\mathrm{X}$ daripada menggunakan teori belajar yang lain. Sebelum dilakukan penerapan teori belajar bermakna peneliti berikan pretest terlebih dahulu kepada siswa dari kelas eksperimen dan kelas kontrol. Adapun data hasil pretest yang digunakan untuk mengetahui kemampuan awal literasi matematis siswa dapat dilihat pada Tabel 3.

Tabel 3. Hasil Uji Statistik Pretest

\begin{tabular}{|l|r|}
\hline \multicolumn{2}{|c|}{ Test Statistics $^{\mathbf{a}}$} \\
\hline & \multicolumn{1}{|c|}{ Pretest } \\
\hline Mann-Whitney U & 87.000 \\
\hline Wilcoxon W & 192.000 \\
\hline Z & -.204 \\
\hline Asymp. Sig. (2-tailed) & .839 \\
\hline $\begin{array}{l}\text { Exact Sig. [2*(1-tailed } \\
\text { Sig.)] }\end{array}$ & $.867^{\mathrm{b}}$ \\
\hline
\end{tabular}

Berdasarkan hasil uji statistik Mann-Whitney yang ditunjukkan pada Tabel 3. diperoleh nilai signifikansi (2-tailed) sebesar 0,839. Hal ini, menunjukkan bahwa nilai signifikansi (2-tailed) lebih besar dari 0,05 , maka dapat disimpulkan bahwa $H_{0}$ diterima. Dengan demikian dapat dikatakan bahwa ada kesamaan hasil pretest antara kelas eksperimen dan kelas kontrol. Karena ada kesamaan yang signifikan maka dapat dikatakan bahwa ada kesamaan kemampuan awal literasi matematis siswa pada kelas eksperimen dan kelas kontrol.

Setelah mengetahui kemampuan awal literasi matematis siswa, selanjutnya peneliti melakukan penerapan teori belajar bermakna David Ausubel pada kelas eksperimen, sedangkan pada kelas kontrol menggunakan teori belajar yang lain. Teori belajar bermakna diterapkan dengan mengaitkan materi sistem persamaan linear tiga variabel dengan aktivitas sehari-hari siswa, melalui kegiatan apersepsi dan permasalahan kontekstual.

Adapun aspek literasi matematis yang diamati pada saat proses pembelajaran yang dilakukan di kelas eksperimen yakni kemampuan siswa dalam memformulasikan masalah, kemampuan siswa dalam menggunakan konsep matematika sebagai strategi penyelesaian masalah, kemampuan siswa dalam menginterpretasikan dan mengevaluasi hasil akhir. Aspek tersebut dapat diketahui melalui pengamatan proses literasi matematis PISA (2018) seperti pada Gambar 1. 


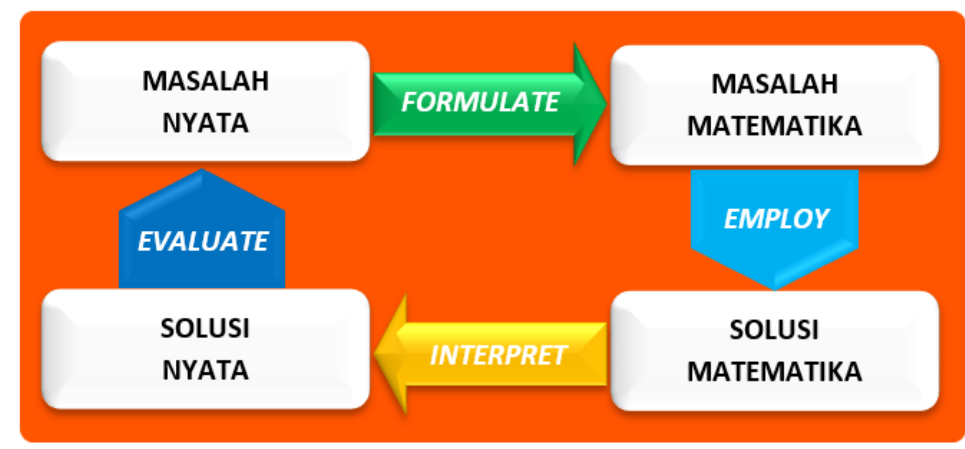

Gambar 1. Proses Literasi Matematis Berdasarkan PISA (2018)

Berdasarkan proses literasi matematis pada Gambar 4.1 tersebut, peneliti menerapkan teori belajar bermakna David Ausubel dengan mengaitkan materi sistem persamaan linear tiga variabel dengan permasalahan kehidupan nyata siswa. Dari permasalahan tersebut siswa memformulasikan masalah ke dalam model matematika yang selanjutnya, siswa menggunakan konsep matematika berupa metode eliminasi, subtitusi, campuran, dan matrik sebagai strategi penyelesaian masalah. Berdasarkan hasil akhir yang sudah ditemukan, siswa mengevaluasi dengan mencocokkan hasil akhir dengan konteks permasalahan. Sehingga diperoleh jawaban yang sesuai dengan konteks yang ditanyakan.

Adapun data hasil posttest yang digunakan sebagai dasar untuk mengetahui kemampuan literasi matematis siswa antara kelas eksperimen yang menggunakan teori belajar bermakna dengan kelas kontrol yang menggunakan teori belajar lain. Data hasil posttest dapat dilihat pada Tabel 4.

Tabel 4. Hasil Uji Statistik Posttest

\begin{tabular}{|l|r|}
\hline \multicolumn{2}{|c|}{ Test Statistics $^{\mathbf{a}}$} \\
\hline \multicolumn{1}{|c|}{ Posttest } \\
\hline Mann-Whitney U & 16.000 \\
\hline Wilcoxon W & 107.000 \\
\hline Z & -3.703 \\
\hline Asymp. Sig. (2-tailed) & .000 \\
\hline Exact Sig. [2*(1-tailed Sig.)] & $.000^{\mathrm{b}}$ \\
\hline
\end{tabular}

Berdasarkan hasil uji statistik Mann-Whitney yang ditunjukkan pada Tabel 4. diperoleh nilai signifikansi (2-tailed) sebesar 0,000. Hal ini, menunjukkan bahwa nilai signifikansi (2-tailed) lebih kecil dari 0,05. Maka dapat disimpulkan bahwa $H_{0}$ ditolak, dengan demikian dapat dikatakan bahwa ada perbedaan hasil posttest antara kelas eksperimen dan kelas kontrol. Karena ada perbedaan yang signifikan maka dapat dikatakan bahwa ada perbedaan kemampuan literasi matematis siswa pada kelas eksperimen dan kelas kontrol.

Selanjutnya untuk mengetahui perbedaan peningkatan kemampuan literasi matematis antara kelas eksperimen dan kelas kontrol dilakukan uji N-Gain. Adapun hasil uji N-Gain pada Tabel 5. 
Penerapan Teori Belajar Bermakna untuk Meningkatkan Literasi Matematis Siswa Kelas X, Nur Wiji Sholikin, Imam Sujarwo, Abdussakir

Tabel 5. Hasil Perhitungan Uji N-Gain Skor

\begin{tabular}{|c|c|c|c|}
\hline \multirow{2}{*}{ Subjek } & Kelas Eksperimen & \multirow{2}{*}{ Subjek } & Kelas Kontrol \\
& N-Gain Skor (\%) & & N-Gain Skor (\%) \\
\hline 1 & 58,33 & 1 & 50,00 \\
\hline 2 & 63,64 & 2 & 60,00 \\
\hline 3 & 70,00 & 3 & 63,64 \\
\hline 4 & 70,00 & 4 & 58,33 \\
\hline 5 & 72,73 & 5 & 54,55 \\
\hline 6 & 66,67 & 6 & 40,00 \\
\hline 7 & 80,00 & 7 & 45,45 \\
\hline 8 & 66,67 & 8 & 50,00 \\
\hline 9 & 87,50 & 9 & 50,00 \\
\hline 10 & 75,00 & 10 & 50,00 \\
\hline 11 & 80,00 & 11 & 62,50 \\
\hline 12 & 80,00 & 12 & 45,45 \\
\hline 13 & 80,00 & 13 & 50,00 \\
\hline 14 & 87,50 & & \\
\hline Rata-rata & 74,1450 & Rata-rata & 52,3019 \\
\hline Minimal & 58,33 & Minimal & 40,00 \\
\hline Maksimal & 87,50 & Maksimal & 63,64 \\
\hline
\end{tabular}

Berdasarkan Tabel 4.3 ditunjukkan bahwa nilai rata-rata N-Gain untuk kelas eksperimen yang menggunakan teori belajar bermakna David Ausubel sebesar 74,1450\% berada pada kategori tinggi. Sedangkan nilai rata-rata N-Gain untuk kelas kontrol yang menggunakan teori lain sebesar 52,3019\% berada pada kategori sedang. Sehingga dapat dikatakan bahwa peningkatan kemampuan literasi matematis pada kelas eksperimen lebih tinggi, jika dibanding dengan kelas kontrol. Hal ini menunjukkan bahwa penerapan teori belajar bermakna David Ausubel dapat meningkatkan kemampuan literasi matematis siswa Madrasah Aliyah kelas X.

\section{Diskusi}

Teori belajar bermakna David Ausubel yang diterapkan pada kelas eksperimen di Madrasah Aliyah Daruttauhid Malang menunjukkan bahwa kemampuan literasi matematis dapat ditingkatkan melalui pembelajaran yang berkaitan dengan kehidupan nyata siswa. Hal ini sejalan dengan Majdi (2019) yang menyatakan bahwa teori belajar bermakna merupakan hasil rekonstruksi pengetahuan dan pengalaman berdasarkan informasi-informasi yang mencakup fakta-fakta, konsep-konsep, ide-ide, dan gagasan yang diperoleh dari kehidupan nyata siswa. Sehingga hal tersebut sesuai dengan literasi matematis yang dikemukakan oleh PISA, (2019) yang menyatakan bahwa literasi matematis merupakan kecakapan menggunakan konsep matematika untuk menyelesaikan berbagai masalah yang berkaitan dengan kehidupan nyata.

Peningkatan kemampuan literasi matematis siswa yang diberikan perlakuan melalui teori belajar David Ausubel pada kelas eksperimen berada pada kategori tinggi dengan nilai rata-rata N-Gain skor 
sebesar 74,1450\%. Hal ini menunjukkan bahwa siswa memenuhi aspek literasi matematis PISA, (2019) yakni kemampuan memformulasikan masalah, kemampuan menggunkan konsep matematika sebagai strategi penyelesaian masalah, kemampuan menginterpretasikan dan mengevaluasi hasil akhir.

Siswa dalam memformulasikan masalah menjadi lebih mudah. Hal itu disebabkan materi dan permasalahan yang diberikan dikaitkan dengan kehidupan nyata siswa (Weilin, 2017). Sehingga siswa lebih mudah dalam memahami permasalahan yang ditanyakan dan mengubahnya ke dalam model matematika. Strategi siswa dalam mengubah permasalahan nyata ke bentuk matematika dilakukan dengan cara mematematiskan permasalahan dengan menuliskan terlebih dahulu informasi-informasi yang diketahui. Selanjutnya, melalui permisalan hingga diperoleh bentuk sistem persamaan linear tiga variabel. Hal ini sejalan dengan Suciana \& Fauzan (2018) yang menyatakan bahwa siswa dapat memahami suatu permasalahan yang berkaitan dengan kehidupan nyata secara matematis melalui hasil konstruksi informasi-informasi baru dengan pengetahuan yang dimiliki.

Dari bentuk sistem persamaan linear tiga variabel yang diperoleh, siswa menghubungkan pengalaman dan pengetahuan barunya sebagai dasar untuk menentukan metode penyelesaian yang tepat dan sesuai. Pada penerapan teori belajar bermakna siswa lebih cenderung suka menyelesaiakan masalah secara open-ended (Gazali, 2016). Hal itu diketahui dari metode penyelesaian yang digunakan siswa bervariasi mulai dari metode eliminasi, substitusi, campuran, dan metode determinan matriks. Kemampuan siswa memilih dan menggunakan metode yang tepat dan sesuai dengan konteks disebut juga sebagai kemampuan menggunakan konsep matematika sebagai strategi penyelesaian masalah (OECD, 2019).

Tidak cukup sampai pada penyelesaian masalah, siswa juga menginterpretasikan hasil jawabannya ke dalam bentuk gambar yang sesuai dengan konteks permasalahan yang ditanyakan. Siswa melakukan kroscek langkah-langkah yang sudah dilakukan hingga memperoleh hasil akhir. Tapi sebelum melakukan kroscek siswa terlebih dahulu menyesuaikan hasil akhir dengan konteks permasalahan. Hal itu dilakukan siswa untuk memperoleh hasil akhir yang tepat dan benar. Sehingga siswa memenuhi aspek literasi matematis pada kemampuan menginterpretasikan dan mengevaluasi hasil akhir (OECD, 2019).

Berdasarkan uraian hasil dan diskusi di atas dapat diketahui bahwa peningkatan literasi matematis siswa kelas X dapat dilakukan melalui penerapan teori belajar bermakna David Ausubel. Melalui teori belajar bermakna siswa dapat menemukan pembelajaran matematika yang bermakna terutama untuk kehidupan sehari-harinya. Siswa mampu dengan mudah memahami materi dan memformulasikan suatu masalah yang berkaitan dengan kehidupan nyata ke dalam model matematika. Sehingga siswa dapat mengaitkan pengetahuan dan pengalamannya untuk menemukan metode penyelesaian yang tepat dan efisien. Dari hasil akhir yang ditemukan siswa juga memiliki inisiatif untuk melakukan kroscek ulang dengan konteks masalah dan melakukan pengecekan 
Penerapan Teori Belajar Bermakna untuk Meningkatkan Literasi Matematis Siswa Kelas X, Nur Wiji Sholikin, Imam Sujarwo, Abdussakir

terhadap langkuh-langkah yang dilakukan. Hal itu dilakukan untuk memperoleh hasil akhir yang benar dan sesuai denga napa yang ditanyakan.

\section{KESIMPULAN}

Berdasarkan hasil dan diskusi yang peneliti uraikan dapat disimpulkan bahwa penerapan teori belajar bermakna dapat meningkatkan literasi matematis siswa kelas X. Hal ini ditunjukkan dari hasil posttest kemampuan literasi matematis siswa berada pada kategori tinggi dengan nilai skor N-Gain sebesar 74,1450\%. Indikator literasi matematis yang dicapai yakni siswa dapat memformulasikan suatu masalah, siswa dapat menggunakan konsep matematika sebagai strategi penyelesaian masalah, siswa dapat menginterpretasikan dan mengevaluasi hasil akhir.

\section{UCAPAN TERIMA KASIH}

Segala puji ke hadirat Allah Swt. yang telah melimpahkan rahmat-Nya, sehingga peneliti mampu menyelesaiakan penulisan artikel ini. Shalawat serta salam selalu terlimpahkan kepada Nabi Muhammad Saw. yang kita nantikan syafaatnya di akhirat nanti. Peneliti mengucapkan terimakasih kepada semua pihak yang telah membantu dalam penyelesaian artikel ini. Semoga artikel ini bermanfaat bagi peneliti dan pembaca. Aamiin.

\section{REFERENSI}

Ahmad, M., \& Nasution, D. P. (2019). Peningkatan Kemampuan Literasi Matematika Siswa Sekolah Menengah Pertama melalui Pendekatan Kontekstual. Jurnal Education and Development, 7(2), 103-112. http://journal.ipts.ac.id/index.php/ED/article/view/883/395

Ariyanto. (2012). Penerapan Teori Ausubel Pada Pembelajaran Pokok Bahasan Pertidaksamaan Kuadrat di SMU. Seminar Nasional Pendidikan Matematika, 2(1), 55-64.

Bolstad, oda heidi. (2019). Teaching for Mathematical Literacy: School Leaders' and Teachers' Rationales. 7(3), 93-108.

Burkhardt, L. A. S. and R. T. with H. (2003). Developing Mathematical Literacy. ProtoSociology, 18(Ml), 139-162. https://doi.org/10.5840/protosociology200318/195

Gazali. (2016). Pembelajaran Matematika yang bermakna. Math Didactic, 2(3), 181-190. https://doi.org/10.33654/math.v2i3.47

Hake, R. R. (1999). Analyzing Change/Gain Scores. Dept. of Physics, Indiana University, 1(1), 1-4. https://doi.org/10.24036/ekj.v1.i1.a10

Hayati, T. R., \& Kamid, K. (2019). Analysis of Mathematical Literacy Processes in High School Students. International Journal of Trends in Mathematics Education Research, 2(3), 116-119. https://doi.org/10.33122/ijtmer.v2i3.70

Majdi. (2019). Analisis Teori Ausubel Pada Penerapan Model Realistic Mathematics Education Dalam Pembelajaran Matematika. Journal AL-MUDARRIS, 2(1), 104. 
https://doi.org/10.32478/al-mudarris.v2i1.213

Nagasaki, E. (2015). Mathematical Literacy for Living in the Highly Information-and-TechnologyOriented in the 21st Century: Mathematics Education from the Perspective of Human Life in Society. Springer International Publishing, 607-628. https://doi.org/10.1007/978-3-319-171876

OECD. (2019a). PISA 2018 Assesment and Analytical Framework. OECD Publishing. https://doi.org/https://doi.org/10.1787/b25efab8-en

OECD. (2019b). PISA 2018 Results. Combined Executive Summaries. Journal of Chemical Information and Modeling, 1(9), 1-25. https://doi.org/10.1017/CBO9781107415324.004

Prihatmojo, A., Agustin, I. M., Ernawati, D., \& Indriyani, D. (2019). Implementasi Pendidikan Karakter di Abad 21. Seminar Nasional Pendidikan Fakultas Ilmu Pendidikan, 180-186.

Saputra, H. (2016). Peningkatan Daya Serap Siswa dalam Pembelajaran Matematika dengan Penerapan Teori Belajar Bermakna David Ausubel. Jurnal Penelitian Pendidikan MIPA, 1(1), 21-26.

Sari, M. P., \& Khiyarunnisa, A. (2017). Problem Based Learning: Upaya Meningkatkan Kemampuan Literasi Matematika Siswa. Seminar Matematika Dan Pendidikan Matematika Uny 2017, 443448.

Suciana, F., \& Fauzan, A. (2018). Pengembangan modul berbentuk komik berbasis kontekstual untuk pembelajaran matematika di sma. Edukasi Dan Penelitian Matematika, 7(1), 60-66.

Umbara, U., \& Suryadi, D. (2019). Re-interpretation of mathematical literacy based on the teacher's perspective. International Journal of Instruction, 12(4), 789-806. https://doi.org/10.29333/iji.2019.12450a

Weilin, D. (2017). Materi Pendukung Literasi Numerasi (Luh Anik Mayani (ed.)). 